\title{
Evaluation of Deficit Irrigation Effects on Sugarbeet Productivity and Control of Root- knot Nematode, Meloidogyne incognita Infection
}

\author{
Maareg, M. F. ; A. Y. El- Gindi ${ }^{* *}$; K. M., Agami and I. M. A., Gohar \\ * Department of Plant Protection, Sugar Crops, Research Institute, Agriculture Research Center, Giza, Egypt. \\ ** Department of Agriculture Zoology and Nematology, Faculty of Agriculture, Cairo University, Giza, Egypt.
}

\begin{abstract}
Water shortages have increased growers interest to investigate the effects of deficit irrigation (DI) levels, i.e. 25,50 and $75 \%$ of irrigation water requirement (IWR) compared with the full irrigation level (100\% of IWR) on sugarbeet productivity and on final population size $\left(\mathrm{p}_{\mathrm{f}}\right)$ and reproduction factor (RF) of root - knot nematode, Meloidogyne incognita, as well as on water use efficiency (WUE) at the end of growing season, under greenhouse conditions. Results showed that DI at the levels of 25,50 , and $75 \%$ of IWR decreased significantly yield characters (root and gross sugar yields) and sugar percent of sugarbeet, and increased WUE compared to full irrigation level $(100 \%)$ treatment, without significant difference between 75 and $100 \%$ DI levels in root yield. The yield characters were greatly reductions at DI levels of 25 and $50 \%$ of IWR. Among the irrigation levels treatments, WUE was lowest in the $100 \%$ irrigation level and highest in the $25 \%$ irrigation level. Also, the results indicated that the $\mathrm{p}_{\mathrm{f}}$ and $\mathrm{RF}$ were significantly lower at irrigation levels of 25 , 50 , and $75 \%$ than $100 \%$ level. The $75 \%$ irrigation level caused minor reductions in root yield, gross sugar yield and sugar percent, but significantly reduced nematode infection $\left(\mathrm{p}_{\mathrm{f}}\right.$ and $\mathrm{RF}$ ) compared to $100 \%$ irrigation level. Thus, deficit irrigation to level of $75 \%$ of IWR can be utilized to the management of root- knot nematode, $M$. incognita infection without significant reduction in sugarbeet yields.
\end{abstract}

Key words: deficit irrigation, $M$. incognita, root- knot nematode, sugarbeet, water irrigation level, water use efficiency, yields.

\section{Introduction}

Sugarbeet (Beta vulgaris L.) is one of the most important crops in Egypt as it is well adapted to Egyptian environment especially reclaimed lands and has essential position in winter crop rotation not only in fertile soils but also in poor, sandy, saline, alkaline and calcareous soils. Also, it is far better than sugarcane when water use efficiency is concerned. One kilogram of sugar needs about 1.4 and $4.0 \mathrm{~m}^{3}$ water by sugarbeet and sugar cane, respectively (Ouda, 2001). Under low water availability, suitable irrigation management and scheduling are indispensable to increase water use efficiency (WUE) in agriculture. Plant parasitic nematodes are 
important sugarbeet pests and considered to be very damaging to crop and cause significant yield losses (Gohar and Maareg, 2005; Maareg et al., 2009 and 2018a). These nematodes that are usually known as the root- knot nematodes, Meloidogyny javanica and $M$. incognita. Sugarbeet plants infected by root-knot nematodes show stunted growth accompanied by symptoms of severe deficiency of some nutritional elements, substantially reduced nutrient and water uptake, and yield amount and quality (Ismail et al., 1996; Maareg et al., 1998; Maareg and Hassanien, 1999; Gohar, 2003; Gohar and Maareg, 2005 and Maareg et al., 2005, 2006, 2009 and 2018a). Root- knot nematodes can survive in a fallow soil for years but survival diminishes quickly if the soil is either too wet or too dry (Towson and Apt, 1983). All Meloidogyne species need water to hatch and hatching is regulated by temperature and moisture (Karssen and Moens, 2006). Soil moisture is an important factor affecting nematode development and infection (Wallace, 1963; Duncan et al., 1998 and Hunter 2000). Increasing water stress decreases the water potential (from 1 to 10 bars) around root-knot nematode, M. javanica, which reduces the percentage of eggs hatching and increases the percentages of second stage juveniles mortality (Mohawesh and Karajeh, 2014). For coping with water shortage and scarce supplies, deficit irrigation, defined as application of water below the full requirement of the crop, is an important tool that achieves the goal of reducing the amount of water required for irrigation. Effects of different deficit irrigation level on sugarbeet performance have been studied by several researchers (Eid and Ibrahim, 2010; Baigy et al., 2012; Asgari et al., 2012; Abdel- Nasser et al., 2014 and Maareg et al., 2018b). Although, deficit irrigation has been widely investigated as a valuable and sustainable production strategy in dry regions (Gearts and Reas, 2009). An additional benefit of deficit irrigation is potential for improving water productivity in many field crops, and there is to decrease the level of infection with some plant pests and diseases, especially those that are moisture dependent (Shin, 2005). Therefore, the main objectives of this study were to compare the effects of deficit irrigation levels (25, 50 and $75 \%)$ with those of full irrigation (100\% of IWR) on sugarbeet productivity and population and reproduction factor of $M$. incognita under greenhouse conditions.

\section{Materials and Methods}

This study was carried out during the growing season of 2015 to compare the effects of selected deficit irrigation levels $(25,50$ and $75 \%)$ with those of full irrigation $100 \%$ of water requirement (IWR) on sugarbeet productivity and population size and reproduction factor of root- knot nematode, $M$. incognita under greenhouse conditions. $30.0 \mathrm{~cm}$ - diameter and $35.5 \mathrm{~cm}$ - deep earthen pots were filled with sterilized sandy loam soil $(65.1 \%$ sand, $22.6 \%$ silt, $12.3 \%$ clay; $0.76 \%$

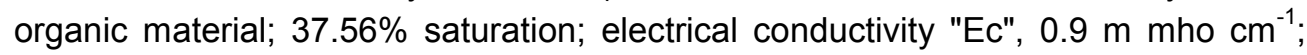
$\mathrm{PH}$ 7.6). Seeds of susceptible sugarbeet, Mammut variety were sown in $7^{\text {th }}$ October, 2015. All pots were placed in saucers and were irrigated with an equal amount of 
water every three days using a volumetric cylinder. At germination pots and after fifteen days, seedlings were thinned to one vigorous plant per pot. The pots were divided into four groups, each contained teen replicates. In total 40 pots were arranged in a randomized complete block design inside the greenhouse at $20 \pm 5 \mathrm{C}^{\circ}$ and $65 \pm 5 \mathrm{RH}$. One week after thinning, the pots were irrigated with a sufficient water volume to reach $100 \%$ of IWR level. The irrigation scheduling was based on the amount of water depleted from the $100 \%$ irrigation level. The amount of irrigation water for the other irrigation levels (25, 50 and $75 \%$ of IWR) was adjusted as a percentage of the full irrigation treatment (100\% of IWR). The amount of irrigation water applied in the $100 \%$ treatment increase the soil water moisture content to IWR level, with no water excesses to prevent leaching of water and inoculants. As the other irrigation levels received less water than the $100 \%$ treatment. The soil water content at $15 \mathrm{~cm}$ - depth was measured six times per month at 5- day intervals was monitored throughout the experiment using time domain reflect meters. Two weeks after thinning, each pot or seedling was inoculated with $10 \mathrm{ml}$ suspension of 2000 freshly hatched second stage juveniles $\left(\mathrm{J}_{2 \mathrm{~s}}\right)$ of $M$. incognita. The inoculation was performed one week after the irrigation level treatments by pouring gently mixed $\mathrm{J}_{2 \mathrm{~s}}$ suspension into three holes made in the soil around the seedling. All sugarbeet potted plant were managed throughout the growing season by standard agricultural practices. Six months after nematode juveniles inoculation, plants were uprooted and root were cleaned. Fresh weight of root was recorded per plant and gross sugar percentage was determined according to Le Docte as described by Mc Ginnis (1982), and gross sugar yield per plant was calculated by multiplied gross sugar $\%$ x root weight. The number of developmental stages per root system was counted after staining with acid fuchsine lacto phenol according to Byrd et al., (1983). The $J_{2 s}$ per pot was extracted using set of 60-350 mesh sieves and modified Baermann pan technique. The final population density $\left(P_{f}\right)$ of nematode for each treatment separately was determined. The reproduction factor (RF) was calculated by the formula: $R F=P_{f} / P i$. Where: $\mathrm{Pi}$ is the initial population. All data were subjected to analysis of variance and Duncan's newmultiple range test used to separate means at $5 \%$ level of probability (Duncan, 1955).

\section{Results and Discussion}

\section{Effect of deficit irrigation levels on sugarbeet productivity:}

Table (1) shows the efficiency of deficit irrigation (DI) levels i.e. 25, 50, 75 and $100 \%$ of IWR on root yield, gross sugar yield and gross sugar percent as well as water use efficiency (WUE) in sandy loam soil. Results showed that the plants at different irrigation levels observed significant differences $(P \leq 0.05)$ in root, gross sugar yields and gross sugar percent. The irrigation with the highest level $(100 \%)$ produced the highest sugarbeet root and gross sugar yield values and the highest 
gross sugar percent, while, irrigation with $25 \%$ level produced the lowest ones. Root yield was significant lower $(P \leq 0.05)$ for sugarbeet plants irrigated with 25 and $50 \%$ levels than these irrigated with 75 and $100 \%$ levels, but plants irrigated at $75 \%$ level did not differ in their root yield from those irrigated at $100 \%$ level. Gross sugar yield significantly decreased $(P \leq 0.05)$ as irrigation water level decreased from 100 to $25 \%$. Also, sugar percent significantly decreased $(P \leq 0.05)$ with decreasing irrigation level, without significant different between the treatments of 50 and $75 \%$ levels. The results in the same Table revealed that the highest DI levels $(50 \%$ and $25 \%$ of IWR) caused the higher reduction (29.59 and $51.76 \%$ ) in root yield, (37.71 and $63.42 \%)$ in gross sugar yield and (11.18 and $24.34 \%)$ in gross sugar percent, respectively. However, the highest DI level (75\%) recorded lower reduction (4.54, 10.83 and $6.8 \%$ ) compared by the full irrigation level (100\% of IWR), in root, gross sugar yields and gross sugar percent, respectively. Irrigation water levels had a significant effect $(P \leq 0.05)$ on WUEs for root and gross sugar yields of sugarbeet. The WUE was significantly higher for sugarbeet plants irrigated with 25,50 , and $75 \%$ levels when compared with plants irrigated with the full $(100 \%)$ irrigation level. The highest WUEs values $\left(29.60\right.$ and $4.01 \mathrm{mg} \mathrm{mm}^{-3}$ for root and gross sugar yields, respectively) were recorded with plants irrigated at the highest deficit irrigation level of $25 \%$ of IWR. The value of WUEs significantly increased $(P \leq 0.05)$ (from 15.06 to $19.19,21.21$ and $29.60 \mathrm{mg} / \mathrm{mm}^{3}$ for root yield and from 2.74 to $3.25,3.41$ and 4.01 $\mathrm{mg} / \mathrm{mm}^{3}$ for sugar yield) with decreasing the irrigation level from 100 to 75,50 and $25 \%$ of IWR, respectively.

Table (1). Efficiency of deficit irrigation levels on root, gross sugar yields and gross sugar percent of sugarbeet infecting with root-knot nematode, Meloidogyne incognita under greenhouse conditions.

\begin{tabular}{|c|c|c|c|c|c|c|c|c|c|c|}
\hline \multirow{2}{*}{ 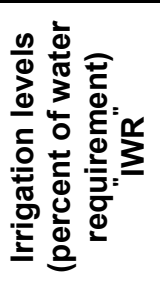 } & \multirow[b]{2}{*}{ 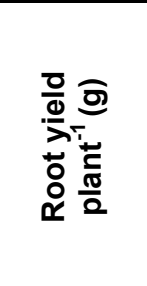 } & \multirow{2}{*}{ 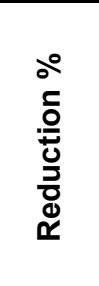 } & \multirow{2}{*}{ 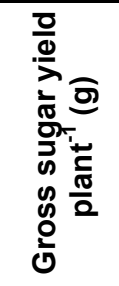 } & \multirow[b]{2}{*}{ 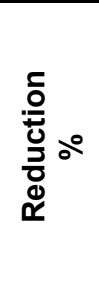 } & \multirow{2}{*}{ 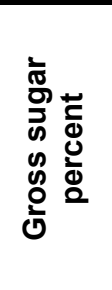 } & \multirow[b]{2}{*}{ 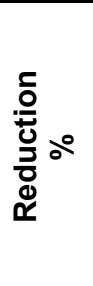 } & \multicolumn{4}{|c|}{$\begin{array}{c}\text { Water use efficiency(WUE) } \\
\mathrm{mg} / \mathrm{mm}^{-3}\end{array}$} \\
\hline & & & & & & & 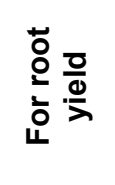 & 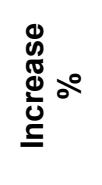 & 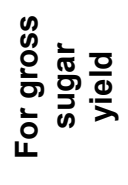 & 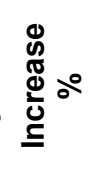 \\
\hline 100 & $1084.20^{\mathrm{a}}$ & - & $197.31^{a}$ & - & $18.24^{\mathrm{a}}$ & - & $15.06^{a}$ & - & $2.74^{\mathrm{a}}$ & - \\
\hline 75 & $1036.00^{\mathrm{a}}$ & 4.45 & $175.95^{b}$ & 10.83 & $17.00^{b}$ & 6.80 & $19.19^{b}$ & 27.42 & $3.25^{b}$ & 18.61 \\
\hline 50 & $763.40^{\mathrm{b}}$ & 29.59 & $122.91^{\mathrm{C}}$ & 37.71 & $16.20^{c}$ & 11.18 & $21.21^{\mathrm{C}}$ & 40.84 & $3.41^{\mathrm{c}}$ & 24.45 \\
\hline 25 & $523.00^{c}$ & 51.76 & $72.17^{d}$ & 63.42 & $13.80^{d}$ & 24.34 & $29.60^{d}$ & 92.96 & $4.01^{d}$ & 51.42 \\
\hline
\end{tabular}

Means in each column followed by the same letter (s) did not significantly differ at $p \leq 0.05$.

The results in this study revealed that decreasing irrigation water level significantly decreased root and gross sugar yields of sugarbeet plants. The 
reduction in yields at irrigation level of $25 \%$ of IWR is caused by a decrease in biomasses production. (Kirnak et al., 2001). Furthermore, water productivity which is the yield or net income per unit of water used (Kijne et al., 2003), is exacted to increase under deficit irrigation relative to its value under full irrigation, as revealed experimentally for many groups (zwart and Bastiaanssen, 2004; Fan et al., 2005 and Fereres and Soriano, 2007). Greater reduction in yield of sugarbeet root and gross sugar occurred at deficit irrigation levels of 50 and $25 \%$ of IWR than at $75 \%$. In this concern, many investigators revealed that increasing amount of irrigation water increased root yield and gross sugar yield (Mohamadian et al., 2004; Gharib and El-Henawy 2011; El-Hawary et al., 2013; Soliman et al., 2013 and Maareg et al., 2018b). Increasing draught period resulted in a significant decreased root and gross sugar yields (Eid and Ibrahim, 2010; Mehrandish et al., 2012 and ElSheref, 2014). Abdel- Naser et al., (2014) reported that irrigation sugarbeet at $60 \%$ of evapotranspiration (ETP) gave a highest roots yield and gross sugar yield. However, El-Kady (2015) observed that sugarbeet plants irrigated at $75 \%$ of IWR recorded the highest significant white sugar yield, while application irrigation water at $100 \%$ of IWR gave the heaviest roots yield.

Also, the results showed that decreasing irrigation water level from 100 to $25 \%$ of IWR significantly decreased gross sugar percent, without significant differences between DI levels of 25 and $50 \%$. Many investigators study the effects of amount of irrigation water on sugar percent and they found that the highest irrigation water volume $\left(2500 \mathrm{~m}^{3} / \mathrm{fed}\right)$ results in highest gross sugar percent (Sharief et al., 1999 and Maareg et al., 2018b). On the other hand, decreasing amount of irrigation water from 3000 to 2500 and $2000 \mathrm{~m}^{3} / \mathrm{fed}$ increased gross sugar percent (El-Hawary et al., 2013). However, Neseim et al., (2014) found that low irrigation level was not significant differences for gross sugar percent. AbdelNasser et al., (2014) observed that the highest gross sugar percent was recorded at level of $60 \%$ of ETP.

The values of $W E_{s}$ significantly increase with decreasing the level of irrigation water from 100 to $25 \%$ of IWP. In this, respect, Sonble et al., (2010) reported that the highest values of $W_{U} E_{s}$ were obtained when sugarbeet plants received the lowest amount of irrigation water, while, the lowest ones were recorded with plants received the highest amount values of irrigation water. The same results recorded by Asgari et al., (2012) and Baigy et al., (2012).

\section{Effects of deficit irrigation levels on root-knot nematode, Meloidogyny} incognita infecting sugarbeet.

Data in Table (2) illustrate effect of deficit irrigation levels on population and reproduction factor of $M$. incognita on sugarbeet plant. It was evident that suppressive effects of DI levels $(25,50$ and $75 \%$ of IWR) was recorded as the nematode population in the soil and root system at the end of the growing season 
(180 days after nematode inoculation). Significantly, the less number of parasitic nematodes was observed in the soil and root system obtained from pots treated with levels of $25 \%, 50 \%$ and $75 \%$ of IWR as compared to the pots treated with the full irrigation level (100\% of IWR) as control treatment. The highest reduction in final nematode population " $\mathrm{P}_{\mathrm{f}}$ " (89.05\%) was recorded with $\mathrm{DI}$ level of $25 \%$ followed by $50 \%$ and $75 \%$ DI levels, with an average of 76.40 and $34.73 \%$, respectively (Table, 2). The reproduction factor (RF) at the end of the sugarbeet growing season was significantly lower $(P \leq 0.05)$ for sugarbeet plants irrigated at 25,50 and $75 \%$ of IWR levels than plants irrigated at $100 \%$ level, but plants irrigated at $25 \%$ level did not differ in their RF from those irrigated at $50 \%$ level.

Table (2). Efficiency of deficit irrigation water level on population density and reproduction factor of root-knot nematode, Meloidogyne incognita infecting sugarbeet plants under greenhouse conditions.

\begin{tabular}{|c|c|c|c|c|c|c|}
\hline \multirow{3}{*}{$\begin{array}{c}\text { Irrigation } \\
\text { levels } \\
\text { (\% of IWR) }\end{array}$} & \multicolumn{4}{|c|}{ Nematode population density } & \multirow{3}{*}{$\begin{array}{c}\text { Reduction } \\
\text { percent }\end{array}$} & \multirow{3}{*}{$\begin{array}{c}\text { Reproduction } \\
\text { Factor (RF) }\end{array}$} \\
\hline & \multirow{2}{*}{$\frac{\text { In soil }}{J_{2 \text { s } \text { pot }^{-1}}}$} & \multicolumn{2}{|c|}{ In root system } & \multirow{2}{*}{$\begin{array}{c}\text { Total } \\
\text { population } \\
\left(P_{\mathrm{f}}\right)\end{array}$} & & \\
\hline & & $\begin{array}{c}\text { Developmental } \\
\text { Stages root }\end{array}$ & $\begin{array}{c}\text { Females } \\
\text { root }^{-1}\end{array}$ & & & \\
\hline & $15778.60^{\mathrm{a}}$ & $2230.40^{\mathrm{a}}$ & $387.60^{\mathrm{a}}$ & $18396.60^{\mathrm{a}}$ & - & $9.20^{\mathrm{a}}$ \\
\hline 75 & $9579.20^{b}$ & $2099.80^{\mathrm{b}}$ & $327.60^{\mathrm{b}}$ & $12006.60^{b}$ & 34.73 & $6.00^{\mathrm{b}}$ \\
\hline 50 & $3480.60^{c}$ & $736.40^{\mathrm{c}}$ & $125.00^{\mathrm{c}}$ & $4342.00^{c}$ & 76.40 & $2.17^{\mathrm{c}}$ \\
\hline 25 & $1333.00^{d}$ & $670.60^{d}$ & $11.00^{d}$ & $2014.60^{d}$ & 89.05 & $1.01^{c}$ \\
\hline
\end{tabular}

Means in each column followed by the same letter(s) did not significantly at $p \leq 0.05$.

In short, the $\mathrm{P}_{\mathrm{f}}$ and $\mathrm{RF}$ of $M$. incognita root-knot nematode were decreased significantly $(P \leq 0.05)$ with decreasing in irrigation level from $100 \%$ to $25 \%$. More significant reduction in these parameters were observed as the irrigation decreased from $75 \%$ to $25 \%$ and the lowest $P_{f}(2014.6)$ and RF (1.01) values were obtained with the lowest irrigation level $(25 \%)$ as shown in Table, 2. Irrigation water is a potential factor that affects the growth, development and survival of nematodes (Prot, 1979 and Towson and Apt, 1983).

In the present study, irrigation as the main factor affected nematode parameters, including sugarbeet infection in terms of final population and its reproduction factor. The final population and reproduction factor of $M$. incognita were much lower for plants irrigated with 25 and 50\% levels than those with 75 and $100 \%$ levels. The DI levels decreased $M$. incognita in sugarbeet accompanied by a small reduction in root and sugar yields and sugar percent at the $75 \%$ irrigation level. DI can be applied to improve the effectiveness of the present control strategies to control root-knot nematodes (Jatala, 1985; Noling and Becker, 1994 
and Mohawesh and Karajeh, 2014) and increase WUEs. Prot (1979) reported that the $\mathrm{J}_{2 \mathrm{~s}}$ of $M$. javanica accumulates most highly at the highest moisture content along a soil moisture gradient. Low soil moisture content reduces $M$. hapla population density and inhibits nematode activity in the soil (Couch and Bloom, 1960). Consequently, managing the amount of irrigation water may reduce nematode development and root infection (Zhang and Schmitt, 2001). Also, Colella et al., (2014) showed that water deficit significantly reduced plant- pest infestation rate.

The results of this study showed that DI practices can be a beneficial technique to increase crop yield production per cubic water unit, and to reduce nematode infection. Little reduction in roots and sugar yields was observed at the $75 \%$ irrigation level, but root- knot nematode infection and population size were significantly reduced $(\mathrm{P} \leq 0.05)$. In conclusion, deficit irrigation to achieve $75 \%$ of water requirement is suitable to increase WUE as well as to enhance the effectiveness of current integrated control strategies to control $M$. incognita without greatly affecting crop performance which ultimately results in increased yield.

\section{References}

Abd El- Nasser, G.; Kh. T., Ben Abdalla; A. M., Osman; I., Gohar and K. M., Agami (2014). Response of sugarbeet yield to deficit irrigation under drip irrigation system. J.Adv.Agric.Res.,19 (3):442-458.

Asgari, A.; F. G, Sahbi; F., Eilali; I. J., Pourkhiz; M. J., Baigy (2012). Effect of deficit irrigation management on components and yield of sugarbeet. Int. J. Agro. \& Plant Production, 3(5):781-787.

Baigy, Maryam J.; F.G., Saaheb; E., Pourkhiz; E., Ejali and A., Asgari (2012). Effect of water stress on sugarbeet production in the tape drip irrigation. Int. Agric. Res. Review, 2 (5):1032-1036.

Byrd, D. W. T., Kirkaptric and K., Barker (1983). An improved technique for clearing and staining plant tissue for detection of nematodes. J. Nematol., 15(3): 142-143.

Colella, T.; V., Candido; G., Campanelli; I., Camele and D., Battaglia (2014). Effect of irrigation regimes and artificial mycorrhization on insect pest infestations and yield in tomato crop. Phytoparasitica, 42: 235-246.

Couch, H.B. and J.R., Bloom (1960). Influence of soil moisture stresses on the development of the root-knot nematode. Phytopathology, 50: 319-321.

Duncan, D. B. (1955). Multiple rang and multiple, F-test Biometrices, 11:1-42.

Duncan, L.W.; R.N., Inserra and D., Dunn (1998). Seasonal changes in citrus fibrous root starch concentration and body length of female, Pratylenchus Coffeae. Nematrobica, 28: 266-263.

Eid, S.M. and M.M., Ibrahim (2010). Irrigation water salinity and irrigation intervals effects on growth, yield and quality of the sugarbeet, in saline soil at middle north nil delta. J. Soil Sci and Agric. Engineering, Mansoura Univ., 1(8):789800. 
El-Hawary M.A., E.M., Soliman; I.M., Abdel-Aziz; M., El-Sherif and Shadia, A., Mohamed (2013). Effect of irrigation water quantity sources and rates of nitrogen on growth, yield and quality of sugarbeet. Res. J. Argic. And. Biolo. Sci., 9(1): 58-69.

El-Kady, M.S.M. (2015). Study of water and fertilization stresses on yield and quality of sugarbeet under two modern irrigation systems in sandy soils. Ph.D. Thesis, Cairo Univ. Fac. Agric., 129 p.

El- Kholi, M.M.M. (2017). Response of sugarbeet to nitrogen and potassium fertilization treatments under different quantities of irrigation water in the sandy soils. Ph.D. Thesis, Alex. Univ. Fac. Agric. (Saba Basha). 104 p.

El-Sheref, Amira, E. (2014). Effect of potassium and boron fertilization on yield and quality of sugarbeet crop under different irrigation intervals in north delta region. Ph.D. Thesis, Kafr El Sheikh Univ. Fac. Agric., 162 p.

Fan, T.; B.A., Stewart; W.A, Payne; Y., Wang; S., Song; J., Luo and C.A., Robinson (2005). Supplemental irrigation and water - yield relationships for plasticulture crops in the loess plateau of china. Agro. J., 97: 177-188.

Fereres, E. and M.A., Soriano (2007). Deficit irrigation for reducing agricultural water use. J. Exp. Botany, 58(2): 147-159.

Gearts, S. and D., Raes (2009). Deficit irrigation as an on- farm strategy to maximize crop water productivity in dry areas. Agric. Water Manag., 96(9): 1275-1284.

Gharib, H.S. and A. S., El- Henawy (2011). Response of sugarbeet (Beta Vulgaris L.) to irrigation regime, nitrogen rate and micronutrients application. Alex. Sci. Exch., 32(2): 140-156.

Gohar, I. M. A. (2003). The relationship between plant parasitic nematodes of sugarbeet and other soil fauna. Ph. D. Thesis, Fac. Agric. Moshtohor Zagazig Univ., Egypt, 221p.

Gohar, I. M. A. and M. F., Maareg (2005). Relationship between crop losses and initial population density of root- knot nematode, Meloidogyne incognita in soil of sugarbeet grown in West Nubariya District. J. Agric. Res., 83(4): 1315-1328.

Hunter, J.J. (2000). Plant spacing effects on root growth and dry matter partitioning of Vitis vinifera cv. Pinot noir / 99 Richter and implications for soil utilization., Acta Horticulture. J 26:63-74.

Ismail, A.E.; H. Z., Aboul- Eid and S. Y., Besheit (1996). Effect of Meloidogyne incognita on growth response and technological characters of certain sugarbeet varieties. Int. J. Nematol., 6: 195-202. 
Jatala, P. (1985). Biology control of nematodes. In: Sasser J.N., Carter C.C (eds), An advanced treatise on Meloidogyne. Raleigh: North Carolina State University Graphics. 303-308 p.

Karssen, G. and M., Moens (2006). Root-knot nematodes, 59-90. In: Perry RN, Moens M. (eds), Plant nematology. Walling Ford, UK, CABI Pub.

Kijne, J.W.; R., Barker and D.J., Molden (2003). Water productivity in agriculture: limits and opportunities for improvement. Wallingford, UK: CABI Pub., 352 p.

Kirnak, H.; C., Kaya; I., Tas and D., Higgs (2001). The influence of water deficit on vegetative growth, physiology, fruit yield and quality in eggplant. Bulgarina, J. Plant Physiol. 27(3-4): 34-46.

Maareg, M. F.; A. M., Ebieda; K. M., Agami and I. M. A., Goher (2006). Effect of irrigation system, and regulated deficit on plant parasitic nematode population in sugarbeet fields at West Nubaryia region. In. The effects of plant parasitic nematode on sugarbeet at Al- Bostan region. Project Funded from National Council of Sugar Crops (NCSC): 63 PP.

Maareg, M. F.; M. A., Hassanein; A. I., Allam and B. A., Oteifa (1998). Susceptibility of twenty-six sugarbeet varieties to root-knot nematodes, Meloidogyne spp., in the newly reclaimed sandy soils of Al- Bostan region. Egypt. J. Agronematol, 2(1): 111- 125.

Maareg, M. F. and M. A., Hassanein (1999). Survey and ecological studies on plant parasitic nematodes in West Nubaryia. In. The effect of nematode in sugarbeet at Al- Bostan region. Project funded from National Council of sugar crops (NCSC). 51 PP.

Maareg, M. F.; I. M. A., Gohar and A. M., Abdel Aal (2005). Susceptibility of twenty-one sugarbeet varieties to root-knot nematode, Meloidogyne incognita at West Nubaryia District. Egypt. Egypt. J. Agric. Res., 83(2):789801.

Maareg, M. F.; A. Y., El- Gindi; Mona, E., El- Shalaby and Abeer, S., Yassin (2009). Evaluation of certain sugarbeet varieties for their productivity and susceptibility to root- knot nematode, Meloidogyne incognita. J. Agric. Sci. Mansura, 34(6): 6851-6861.

Maareg, M. F.; A.Y. El-Gindi; Mona, E. El- Shalaby and Abeer. S. Yassin (2018a). Evaluation of some sugarbeet varieties for their susceptibility to root- knot nematode, Meloidogyne incognita, according to modified host parasite index (MHPI) scale. Egypt. J. Agronematol., 17(1): 1-12.

Maareg, M.F.; M. A., Gomaa; G., Abdel- Nasser; A.M., Ebieda; K.M., Agami and M.M. El- Kholi (2018b). Sugarbeet response to irrigation deficit irrigation, nitrogen and potassium rates under drip irrigation, under publication. 
Mehrandish, M.; M. J., Moeini and M., Armin (2012). Sugarbeet (Beta Vulgaris L.) response to potassium application under full and deficit irrigation. European J. Experimental Bio., 2(6): 2113-2119.

Mohamadian, R.; M., Ahmed and S., Ghalebi (2004). Effects of potassium application under different irrigation intervals on yield and water use efficiency of two genotypes of sugarbeet in furrow irrigation. J. Sugarbeet., 20(5): 55-72.

Mohawesh, O. and M., Karajeh (2014). Effects of deficit irrigation on tomato and eggplant and their infection with the root-knot nematode under controlled environmental conditions. Arch. Agro. \& Soil Sci., 60(8): 1091- 1102.

Mc Ginnis, R. A. (1982). Beet sugar technology $3^{\text {rd }}$ ed. sugarbeet development foundation Fort Collins, $855 \mathrm{p}$.

Neseim, M. R.; A. Y., Amin and M. M. S., El- Mohamady (2014). Effect of potassium applied with foliar spray of yeast on sugarbeet growth and yield under drought stress. Global Adv. Res. J. Agric. Sci., 3(8): 211-222.

Noling, J. W. and J. O., Becker (1994). The challenge of research and extension to define and implement alternatives to methyl promide. J. Nematol., 26: 573-586.

Ouda, Soher, M. M. (2001). Response of sugarbeet to $\mathrm{N}$ and $\mathrm{K}$ fertilizers levels under sandy soil conditions. Zagazig J. Agric, Res., 28(2): 275-297.

Prot, J. C. (1979). Horizontal migration of second- stage juveniles of Meloidogyne javanica in sand in concentration gradients of salts and in a moisture gradient. Revue de Nematology, 2: 17-21.

Sharief, A. E.; M. S., Sultan; A. N., Attia; M. A. M., Ibrahim and T. K., Emara (1999). Role of plant population and water quality on growth yield and quality of sugarbeet in North Nile Delta. First International Conf. On: Sugar and integrated Industries, Present and Future, Luxor, Egypt, 15-18 Feb., 208-2016.

Shin, S.H. (2005). Effect of irrigation systems, partial root zone drying irrigation and regulated deficit on plant parasitic nematode population in grapevine. M.sc. Thesis, Unv. Western Australia. 75p.

Soliman, E.M.; M.A., El- Hawary; I.M., Abdel-Aziz; O. A.O., Mazen and Shadia, A., Mohamed (2013). Effect of irrigation water quality, sources and rates of nitrogen on growth and quality of sugarbeet. J. Plant Production, Mansoura Univ., 4(4): 537-550.

Sonbol, H.A.; E.M., El-Hadidi; M. M., Said and H.M., Abo El- Soud (2010). Effect of different surface and drip irrigation systems on sugarbeet yield, irrigation performances and soil salinity at North Delta. J. Soil. Sci. and Agri. Engineering 1(4): 407-420. 
Towson, A. J. and W. J., Apt (1983). Effects of soil water potential on survival of Meloidogyne javanica in fallow soil. J. Nematol., 15: 110-115.

Wallace, H. R. (1963). Biology of plant parasitic nematodes. Edward Arnold Ltd., London, $280 \mathrm{p}$.

Zhang, F. and D. P., Schmitt (2001). Plant parasitic nematodes in the Waimanalo, Hawaii irrigation system from watershed to farm. Nematol., 33: 294-296.

Zwart, S. J. and W. G. M., Bastiaanssen (2004). Review of measured crop water productivity values for irrigated wheat, rice, cotton and maize. Agric. Water manage. 69(2): 115-133. 


\section{تقييم تأثير تناقص كمية مياه الري علي إنتاجية بنجر السكر}

\section{ومقاومة نيماتودا تعقد الجذور (Meloidogyne incognita)}

محمد فتحي معارج*، عبد المنعم الجندي**، كمال محمد عجمي*، إبراهيم محمد عبده

$$
\text { جوهر }
$$

$$
\begin{aligned}
& \text { * قسم وقاية النباتات، معهد بحوث المحاصيل السكرية، مركز البحوث الزراعية، جيزة، مصر. }
\end{aligned}
$$

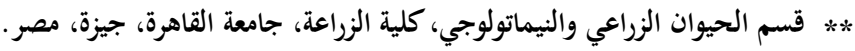

$$
\begin{aligned}
& \text { الملخص العبي }
\end{aligned}
$$

نظرًا للتناقص الشديد في الموارد المائية كان الهدف الرئيسي من هذه الدراسة هو تقييم تأثير

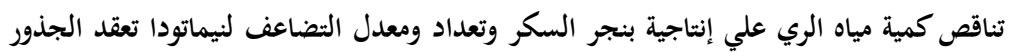

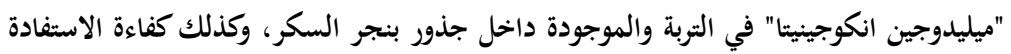

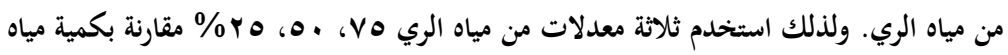

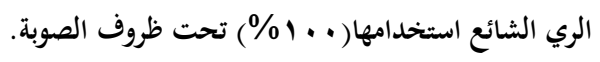

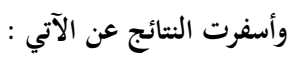

- محصول الجذور ومحصول السكر ونسبة السكر نقصت جوهريًّا بتناقص معدل كمية الري

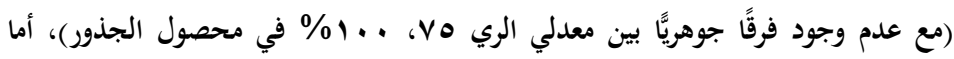

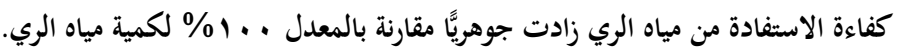

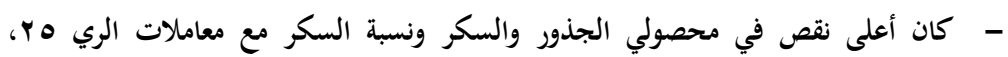

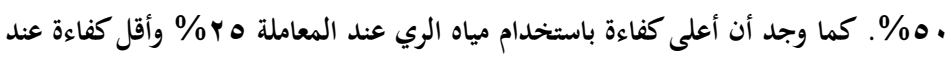

$$
\text { المعدل . . 1 \% من كمية مياه الري. }
$$

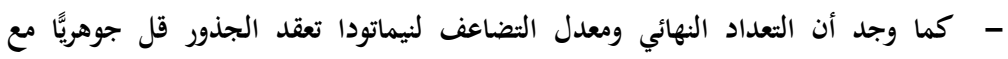

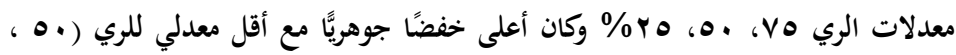

$$
\text { . \% \% ro }
$$

- معدل الري 0V\% حقق أقل خفضا في محصولي الجذور والسكر ونسبة السكر، بينما

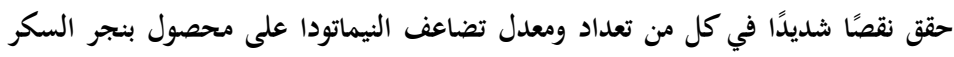

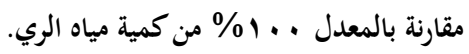

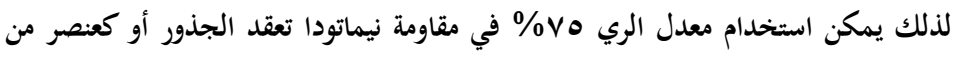

عناصر المكافحة المتكاملة لتأثيره الشديد في خفض تعداد نيماتودا تعقد الجذور في حقول بنجر لمعرد

$$
\text { السكر دون المساس الجوهري للمحصول. }
$$

